\title{
Soil Microbial Status and Methane Emission under Waste Materials Application in Rice Paddy Field
}

\author{
ABM Forhad ${ }^{1}$, Rehana Khatun ${ }^{1 *}$ and Md Zahurul Islam² \\ ${ }^{1}$ Department of Environmental Science, Bangladesh Agricultural University, Bangladesh \\ ${ }^{2}$ Division of Soil Science, Bangladesh Institute of Nuclear Agriculture, Bangladesh
}

Submission: March 05, 2019; Published: March 22, 2019

*Corresponding author: Rehana Khatun, Professor, Department of Environmental Science, Bangladesh Agricultural University Mymensingh-2202, Bangladesh

\begin{abstract}
A study was performed to investigate the effects of waste materials on soil microbial communities and methane $\left(\mathrm{CH}_{4}\right)$ emission in Boro rice season (December 2015 to April 2016) at Environmental Science Field Laboratory of Bangladesh Agricultural University, Mymensingh, Bangladesh. The field experiment comprised of 5 treatments: T1 (control i.e., no fertilizer), T2 (100\% chemical fertilizer), T3 (50\% well decomposed farm waste $+50 \%$ chemical fertilizer), T4 ( $50 \%$ well decomposed kitchen waste $+50 \%$ chemical fertilizer), T5 (50\% well decomposed municipal solid waste $+50 \%$ chemical fertilizer). The experiment was laid out in randomized complete block design (RCBD) with three replications. Population of bacteria, fungi and nematode was counted from post-harvest soil. $\mathrm{CH}_{4}$ emission, plant height and leaf area index (LAI) were recorded at active tillering stage, flowering stage, and mature stage. The bacterial, fungal and nematode populations were much higher in waste materials treated plots compared to un-fertilized and $100 \%$ chemical fertilizer applied plots. $\mathrm{The}_{4} \mathrm{CH}_{4}$ emission was higher at active tillering stage in treatment T5 $\left(51.20 \mathrm{mg} \mathrm{m}^{-2} \mathrm{~h}^{-1}\right)$ and then T4 $\left(44.8 \mathrm{mg} \mathrm{m}^{-2} \mathrm{~h}^{-1}\right)$ while the lowest was in T1 treatment at all stages of rice growth. Growth and yield were also higher under combined organic waste and chemical fertilizer applied plots over control and no significant variation was found among waste materials. This study revealed that well decomposed farm waste along with chemical fertilizers could be more effective in improving microbial populations, growth and yield of rice and for decreasing $\mathrm{CH}_{4}$ emission.
\end{abstract}

Keywords: Bacteria; Fungi; Nematode; $\mathrm{CH}_{4}$ emission; Waste materials

\section{Introduction}

Bangladesh is an agro-based country where agriculture is considered as backbone of her economy. However, the fertility status of soil has been declining continuously due to intensive cropping and imbalanced use of chemical fertilizers to meet up growing demand of food. Continuous use of chemical fertilizers like urea deteriorates soil properties and causes nutrient imbalance of soil in addition to causing micronutrient deficiency. Nutrient mining, depletion of soil organic matter, reduction of soil microbes (e.g., bacteria, fungi, protozoa, algae etc.) have been identified as important factors for declining soil productivity [1]. On the other hand, waste management is considered to be one of the most serious environmental problems in Bangladesh [2]. Waste volumes continue to rise with increasing population, which leads to loss of resources and increase environmental risks. As waste materials are rich sources of macro and micro nutrients, soil quality may improve by the addition of several kinds of waste materials (e.g., household waste, municipal waste, sewage sludge, agricultural and industrial wastes, animal manure etc.) in agricultural land [3$4]$.
Soil microorganisms (e.g., bacteria, algae, fungi, protozoa etc.) play an important role in decomposing organic matter, nutrients and carbon cycling and maintaining soil fertility. Changes in the composition of soil microbiota have been taken as sensitive indicators of soil health and ecosystems [5]. Microbial communities in the soil are enhanced and stimulated by the addition of organic waste due to the presence of high levels of macronutrients such as $\mathrm{N}, \mathrm{P}, \mathrm{K}, \mathrm{Ca}$ and micronutrients such as $\mathrm{B}, \mathrm{Zn}$ and $\mathrm{Mn}$ [2]. However, some composted waste materials have been found to influence essential soil organisms and can be added to the soil without any risk [6-7], whereas some others can produce toxic and depressant effects on plants and the microbial communities [8]. In addition, microbial decomposition of waste materials will lead to production of greenhouse gases $\left(\mathrm{CO}_{2}, \mathrm{~N}_{2} \mathrm{O}\right.$ or $\left.\mathrm{CH}_{4}\right)$. Since the increasing concentrations of greenhouse gases contribute to the enhancement of greenhouse effects as well as to climate change [9], there is a growing interest in quantifying the significant sources and sinks of these trace gases. The objectives of this study were: 
i) to investigate the effect of waste materials on soil microbial communities,

ii) to quantify the effect of waste materials on the rate of $\mathrm{CH}_{4}$ emission and

iii) to assess the effect of waste materials on growth and yield of crop.

\section{Materials and Methods}

\section{Study area}

The experiment was set up at Environmental Science Field Laboratory of Bangladesh Agricultural University, Mymensingh, Bangladesh. The farm is situated at the latitude of $24.75^{\circ} \mathrm{N}$ and longitude of $90.5^{\circ} \mathrm{E}$.

\section{Experimental design}

The experiment was laid out in Randomized Complete Block Design (RCBD) with 5 treatments: T1: No chemical fertilizer and no waste materials (Control); T2: 100\% chemical fertilizer; T3: $50 \%$ well decomposed farm waste $+50 \%$ chemical fertilizer; $\mathrm{T} 4$ : $50 \%$ well decomposed kitchen waste $+50 \%$ chemical fertilizer and $\mathrm{T} 5=50 \%$ well decomposed municipal solid waste $+50 \%$ chemical fertilizer. The experimental area was divided into 3 blocks representing the replications to reduce soil heterogeneity effects. Thus, total numbers of unit plots were 15 . The unit plot size was $4 \times 2.5=10 \mathrm{~m}^{2}$ and plots were separated from each other by dike $(50 \mathrm{~cm})$.

The recommended chemical fertilizer doses were: Urea: 267gm / plot; TSP: 109gm / plot; MOP: 134gm / plot; Zinc Sulphate: 10gm / plot and Gypsum: 59gm / plot. The chemical properties (N, P, K, S) of farm waste, kitchen waste and municipal waste were analyzed and the amount of waste materials for each plot was calculated. Based on the nutrient content of waste materials, $4 \mathrm{~kg}$ farm waste, $6 \mathrm{~kg}$ kitchen waste and $5 \mathrm{~kg}$ municipal waste was applied at treatment T3, T4 and T5, respectively.

\section{Crop establishment}

The land was first opened on December 2015. Each experimental plot was fertilized following their doses. Half dose of urea and full doses of the other fertilizers (TSP, MOP, Gypsum, Zinc Sulphate) and waste materials were applied to the field during final land preparation. The rest of urea fertilizer was applied to the land after 40 days of transplanting.

Forty days old seedlings of BRRI dhan28 were transplanted in the experimental plot on 20 January 2016 maintaining two seedlings per hill with $25 \mathrm{~cm} \times 25 \mathrm{~cm}$ row and hill spacing. Necessary intercultural operations were done for maintaining the normal growth and development of the crop.

\section{Data collection}

Collection of soil sample: Post-harvest soil sampling was done plot wise accordingly at plough depth $(15 \mathrm{~cm})$ level. Soil samples were analyzed in the Laboratory of Soil Science Division, Bangladesh Institute of Nuclear Agriculture (BINA), Mymensingh for counting bacteria, fungi and nematode populations as well as for chemical properties.

Analysis of soil samples: The total soil nitrogen $(\mathrm{N})$ was determined by semi micro-Kjeldahl method [10]. Available phosphorous (P) was diagnosed from the soil following the method of Olsen [11]. Exchangeable potassium (K) and sulphur (S) was analyzed using flame photometer [12] and spectrophotometer [13], respectively.

Ten gm soil from each sample was taken into $250 \mathrm{ml}$ erlenmeyer flask contained $90 \mathrm{ml}$ sterile water and made volume $100 \mathrm{ml}$ and shaken well on electric rotary shaker for half an hour. From that suspension $1 \mathrm{ml}$ was transferred to $9 \mathrm{ml}$ sterile water containing wide mouth vial. Dilution of the suspension up to $10^{-7}$ was made using serial dilution technique. A $0.1 \mathrm{ml}$ of suspension from each dilution was spread out on Nutrient Agar medium containing petriplates and incubates at $30^{\circ} \mathrm{C}$ for 3 days. Well separated single colonies showing characteristics of bacteria from each dilution were counted using plate count method. Methodology of counting fungi is same as bacterial count where Potato Dextrose Agar medium was used.

Two hundred fifty gm soil sample was placed in a plastic bucket and was stirred with hand and broken up clumps of soils while adding tap water (approx. 3/4 full). After 30 minutes when suspension became uniform, the suspension sieved through 20 mesh sieves at one time (leaving the settled sediment at the bottom of the bucket). Then 20 mesh sieves were discarded, and cysts and large eel shaped forms collected from 60 mesh sieve by back washing into $250 \mathrm{ml}$ beaker. Other eel shaped forms were collected from back washing of 325 mesh sieve in separate $250 \mathrm{ml}$ beaker. A 3\% formaldehyde fixative solution (8 parts medium and 92-parts water) was used to kill the nematode. Then nematodes were counted.

\section{Gas sampling and analysis}

Gas samples were collected by the modified closed-chamber method [14] at different growth stages (active tillering, flowering and mature stage) to get the average $\mathrm{CH}_{4}$ emissions during the cropping season. A rectangular chamber $(60 \times 60 \times 90 \mathrm{~cm})$ was placed over the rice planted plot. Immediately after setting the chamber, air sample was collected with an empty $50 \mathrm{ml}$ syringe from inside the chamber and was injected into $50 \mathrm{ml}$ air-tight vials. Again, the sample was collected in $50 \mathrm{ml}$ air-tight vials at 15and 30-minutes intervals. The concentration of $\mathrm{CH}_{4}$ gas was determined by gas chromatograph (Shimadzu 2014, USA) equipped with a Flame Ionization Detector (FID).

According to Rolston [15], $\mathrm{CH}_{4}$ flux was calculated using following formula:

$$
F=\rho \cdot \frac{V}{A} \times \frac{\Delta c}{\Delta t} \times \frac{273}{T}
$$


Where, $\mathrm{F}=\mathrm{CH}_{4}$ flux $\left(\mathrm{mg} \mathrm{m}^{-2} \mathrm{hr}^{-1}\right) ; \rho=\mathrm{CH}_{4}$ gas density $(0.714 \mathrm{mg}$ $\left.\mathrm{cm}^{-3}\right) ; \mathrm{V}=$ volume of the chamber $\left(\mathrm{m}^{3}\right) ; \mathrm{A}=$ surface area of the chamber $\left(\mathrm{m}^{2}\right) ; \Delta \mathrm{c} / \Delta \mathrm{t}=$ rate of increase of $\mathrm{CH}_{4}$ gas concentration in the chamber $\left(\mathrm{mg} \mathrm{m}^{-3} \mathrm{hr}^{-1}\right)$; and $\mathrm{T}=273+$ mean temperature of the chamber $\left({ }^{\circ} \mathrm{C}\right)$.

Growth and yield of rice: Two growth indicators (plant height and leaf area index) were measured at active tillering stage, flowering stage and mature stage. Rice was harvested plot-wise at maturity (28 April 2016). Yield of rice and straw per plot was recorded at final harvest.

\section{Results and Discussion}

The study was conducted at the Environmental Science Field Laboratory of Bangladesh Agricultural University, Mymensingh to evaluate the effects of farm waste, kitchen waste and municipal waste on soil microbial population and methane gas emission from rice field.

\section{Physicochemical properties of soil}

The soil of the experimental field belongs to the Sonatola soil series of noncalcareous dark grey floodplain under the Old Brahmaputra Alluvial Tract which is more or less neutral in reaction with $1.80 \%$ organic matter content and $\mathrm{pH}$ value 6.5 . The experimental field was medium high land with well drained condition. The soil texture was silty loam.

The average values of total nitrogen $(\mathrm{N})$ content were $0.107 \%$, $0.145 \%, 0.140 \%, 0.128 \%$ and $0.134 \%$ in treatment $\mathrm{T} 1$ (control), T2 (100\% chemical fertilizer ), T3 (50\% well decomposed farm waste $+50 \%$ chemical fertilizer), T4 (50\% well decomposed kitchen waste $+50 \%$ chemical fertilizer) and T5 (50\% well decomposed municipal solid waste $+50 \%$ chemical fertilizer), respectively. Highest was found in $100 \%$ chemical fertilizer treated plot and lowest was found in control plot. Phosphorous (P) content ranged from $6.71 \mathrm{ppm}$ to $7.62 \mathrm{ppm}$ where highest was found in T5 treatment and lowest was found in T1 treatment. The average values of exchangeable $\mathrm{K}$ ranged from 41.0 to $72.2 \mathrm{ppm}$ and it was 41.0, 72.2, 64.4, 48.0 and $60.1 \mathrm{ppm}$ in treatment T1 (control), T2 (100\% chemical fertilizer), T3 (50\% well decomposed farm waste + 50\% chemical fertilizer), T4 (50\% well decomposed kitchen waste $+50 \%$ chemical fertilizer) and T5 (50\% well decomposed municipal solid waste $+50 \%$ chemical fertilizer), respectively. It was highest in $\mathrm{T} 2$ treatment and was lowest in T1 treatment. The average values of sulphur (S) content were 10.08, 7.69, 8.87, 12.42 and $10.05 \mathrm{ppm}$ in treatment T1 (control), T2 $1100 \%$ chemical fertilizer ), T3 (50\% well decomposed farm waste $+50 \%$ chemical fertilizer), T4 (50\% well decomposed kitchen waste $+50 \%$ recommended chemical fertilizer) and T5 (50\% well decomposed municipal solid waste $+50 \%$ chemical fertilizer), respectively. S content was highest in treatment T4 and lowest in treatment T2.

\section{Effects of waste materials on soil microbial community}

The bacterial population was $0.14 \times 10^{6}, 0.21 \times 10^{6}, 5.0 \times 10^{6}$, $7.2 \times 10^{6}, 5.4 \times 10^{6} \mathrm{CFU} / \mathrm{g}$ soil in treatment T1 (control), T2 $(100 \%$ chemical fertilizer), T3 (50\% well decomposed farm waste $+50 \%$ chemical fertilizer), T4 (50\% well decomposed kitchen waste + $50 \%$ chemical fertilizer) and T5 (50\% well decomposed municipal solid waste $+50 \%$ chemical fertilizer), respectively (Figure 1a). Vertical bar indicates the standard error. Bacterial population was increased by the application of farm waste, kitchen waste and municipal solid waste in soil compared to control and chemical fertilizer application. Some researchers indicated that the application of organic fertilizers increased the bacterial population in the soil environment [16]. The highest population of bacteria was found in kitchen waste treated plot compared to farm waste and municipal solid waste applied plot.
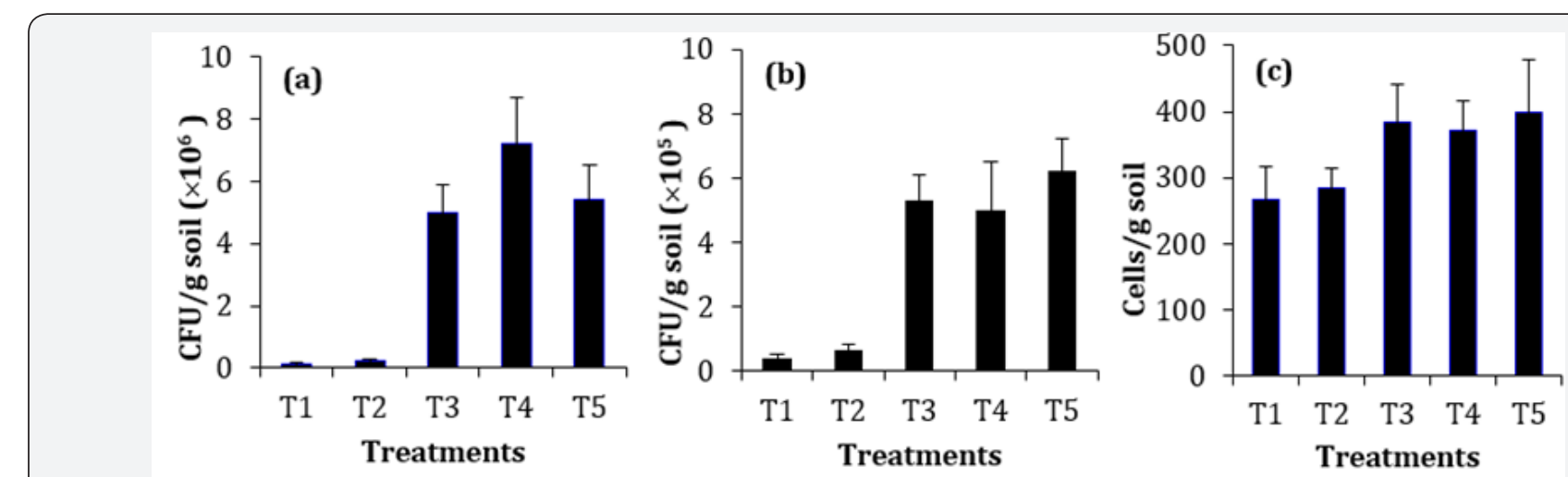

Figure 1: (a) Bacterial population, (b) fungal population and (c) nematode population under different treatments (CFU- colony forming unit).

Fungal population in soil under different treatments ranged from $0.41 \times 10^{5} \mathrm{CFU} / \mathrm{g}$ to $6.2 \times 10^{5} \mathrm{CFU} / \mathrm{g}$ soil (Figure $1 \mathrm{~b}$ ). The highest fungal population was found in treatment $\mathrm{T} 5$ (50\% well decomposed municipal solid waste $+50 \%$ chemical fertilizer $)$ $\left(6.2 \times 10^{5} \mathrm{CFU} / \mathrm{g}\right)$ followed by treatment $\mathrm{T} 3(50 \%$ well decomposed farm waste $+50 \%$ chemical fertilizer $)\left(5.3 \times 10^{5} \mathrm{CFU} / \mathrm{g}\right)$ and $\mathrm{T} 4$ ( $50 \%$ well decomposed kitchen waste $+50 \%$ chemical fertilizer) $\left(5.0 \times 10^{5} \mathrm{CFU} / \mathrm{g}\right)$. Fungal population was lowest in treatment T1 Organic waste application had a higher effect on fungal population in the paddy field is also reported by previous study [17]. 
The nematode populations were 267, 285, 385, 372 and 399 cell/g soil in treatment T1 (control), T2 (100\% chemical fertilizer), T3 (50\% well decomposed farm waste $+50 \%$ chemical fertilizer), T4 (50\% well decomposed kitchen waste $+50 \%$ chemical fertilizer) and T5 (50\% well decomposed municipal solid waste $+50 \%$ chemical fertilizer), respectively (Figure 1c). Highest population of nematode was found in treatment $\mathrm{T} 5$ and lowest was found in treatment T1. Decomposed waste materials application had a great effect on nematode population in the paddy field [18].

Waste materials have positive effects on carbon mineralization [19]. The higher microbial populations in all waste materials amended plots were probably due to the contribution of waste materials for readily available organic $\mathrm{C}$ and nutrients to soil microorganisms.

\section{Effects of waste materials on $\mathrm{CH} 4$ emission}

$\mathrm{CH}_{4}$ emission was recorded in different stages of rice cultivation namely active tillering stage, flowering stage and mature stage.

At the active tillering stage, the highest $\mathrm{CH}_{4}$ emission $(51.20 \mathrm{mg}$ $\mathrm{m}^{-2} \mathrm{~h}^{-1}$ ) was observed in the treatment $\mathrm{T} 5$ that contained $50 \%$ well decomposed municipal solid waste $+50 \%$ chemical fertilizer (Figure 2). The second highest $\mathrm{CH}_{4}$ emission $\left(44.8 \mathrm{mg} \mathrm{m}^{-2} \mathrm{~h}^{-1}\right.$ ) was observed at treatment T4 (50\% well decomposed kitchen waste $+50 \%$ chemical fertilizer). In this stage, the lowest $\mathrm{CH}_{4}$ emission $\left(2.53 \mathrm{mg} \mathrm{m}^{-2} \mathrm{~h}^{-1}\right)$ was found in the control plot. Highest $(44.47 \mathrm{mg}$ $\left.\mathrm{m}^{-2} \mathrm{~h}^{-1}\right)$ and lowest $\mathrm{CH}_{4}$ emission $\left(8.39 \mathrm{mg} \mathrm{m}^{-2} \mathrm{~h}^{-1}\right)$ was observed from rice cultivation with organic and no fertilizer application in the earlier study [20], which had a great similarity with the present study.

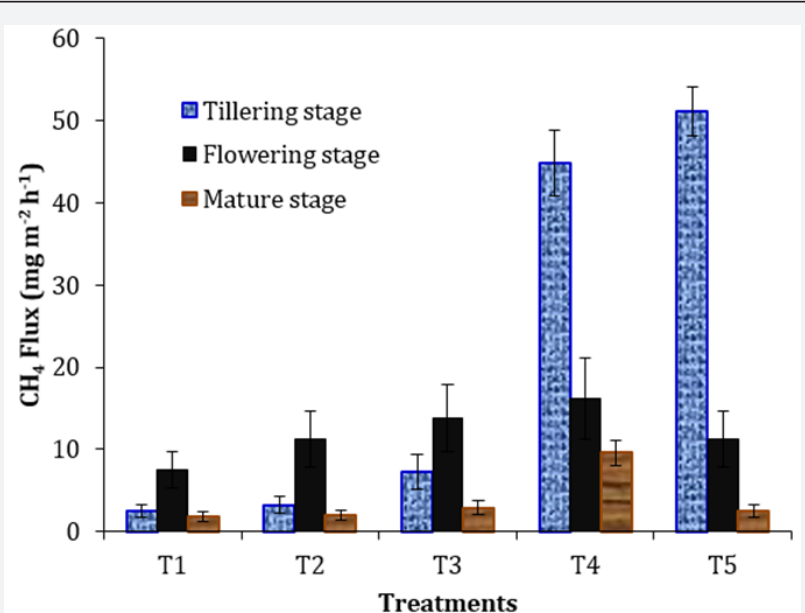

Figure 2: $\mathrm{CH}_{4}$ emission at different growth stages of rice cultivation under different treatments.

At the flowering stage, the $\mathrm{CH}_{4}$ emission was highest $(16.21 \mathrm{mg}$ $\mathrm{m}^{-2} \mathrm{~h}^{-1}$ ) with the treatment of T4 (50\% well decomposed kitchen waste $+50 \%$ chemical fertilizer) (Figure 2), the second highest $\left(13.82 \mathrm{mg} \mathrm{m}^{-2} \mathrm{~h}^{-1}\right)$ was found with the application of $50 \%$ well decomposed farm waste $+50 \%$ chemical fertilizer in $\mathrm{T} 3$ treatment. The lowest $\left(7.5 \mathrm{mg} \mathrm{m}^{-2} \mathrm{~h}^{-1}\right.$ ) was found in control treatment T1 (Figure 2). In this stage, $\mathrm{CH}_{4}$ gas emission rate is lower than active tillering stage . Application of organic materials enhanced methane emission from rice fields is also reported by previous study [21].

The $\mathrm{CH}_{4}$ emission at mature stage were 1.81, 2.01, 2.92, 9.57 and $2.5 \mathrm{mg} \mathrm{m}^{-2} \mathrm{~h}^{-1}$ in treatment T1 (control), T2 (100\% chemical fertilizer), T3 (50\% well decomposed farm waste $+50 \%$ chemical fertilizer), T4 (50\% well decomposed kitchen waste $+50 \%$ chemical fertilizer) and T5 (50\% well decomposed municipal solid waste $+50 \%$ chemical fertilizer), respectively (Figure 2). The highest $\mathrm{CH}_{4}$ emission $\left(9.57 \mathrm{mg} \mathrm{m}^{-2} \mathrm{~h}^{-1}\right)$ was observed in the treatment of $\mathrm{T} 4$ that contained $50 \%$ well decomposed kitchen waste + $50 \%$ chemical fertilizer. The lowest $\mathrm{CH}_{4}$ emission $\left(1.81 \mathrm{mg} \mathrm{m}^{-2} \mathrm{~h}^{-1}\right)$ was found in the control plot.
At different stages of rice cultivation i.e., in active tillering stage, flowering stage and mature stage, the lowest $\mathrm{CH}_{4}$ emissions were found in control plots at the rate of $2.53,7.5$ and $1.80 \mathrm{mg}$ $\mathrm{m}^{-2} \mathrm{~h}^{-1}$, respectively. High rate of $\mathrm{CH}_{4}$ emissions were found at the treatments of T5 and T4. But the highest average $\mathrm{CH}_{4}$ emission was found in treatment T4. The application of organic waste increased the $\mathrm{CH}_{4}$ emission from rice field at various stages of rice production. The changes in the management of organic fertilizers have been identified as the main driving force for long term changes of $\mathrm{CH}_{4}$ emission from rice field [22]. The increment in $\mathrm{CH}_{4}$ emissions following organic fertilizer application depends on quantity, quality and timing of the application of organic fertilizer [23]. An earlier study also revealed that the $\mathrm{CH}_{4}$ emission was higher from plots applied with farm waste than plot applied only with chemical fertilizer [24].

Researchers of previous study stated that readily mineralizable carbon is one of the main factors affecting $\mathrm{CH}_{4}$ emissions from flooded rice field [23]. As waste materials have positive correlation with readily mineralizable carbon, therefore, $\mathrm{CH}_{4}$ emissions were higher in waste materials treated plot compared to others. 


\section{Effects of waste materials on growth and yield}

Highest plant height was found in T5 Treatment (50\% well decomposed municipal solid waste $+50 \%$ chemical fertilizer) and plant height was $46.9,80.04$, and $101.06 \mathrm{~cm}$ at active tillering stage, flowering stage, and mature stage, respectively. The lowest plant height was found in the treatment T1 (control) at all growth stages of rice Some researchers reported that the application of organic waste increased the plant height [25]. The highest leaf area index (LAI) (5.02) was found in the treatment of T5 (50\% well decomposed municipal solid waste $+50 \%$ chemical fertilizer). The lowest (1.08) was found in the treatment T1 (control). The order of the treatment for LAI was T5 $>\mathrm{T} 3>\mathrm{T} 4>\mathrm{T} 2>\mathrm{T} 1$. Use of organic fertilizers increased the plant growth and leaf number as LAI and combined application of NPKS and organic manures increased the leaf area of rice [26].

The grain yield ranged from 3.27 to $6.20 \mathrm{t} \mathrm{ha}^{-1}$ under different treatments (Figure 3a). All the treatments produced higher grain yield over control. The lowest grain yield of $3.27 \mathrm{t} \mathrm{ha} \mathrm{H}^{-1}$ was obtained in control treatment (T1) and the highest grain yield of $6.20 \mathrm{tha}^{-1}$ was obtained in treatment $\mathrm{T} 4$ (50\% well decomposed kitchen waste $+50 \%$ chemical fertilizer). Grain yield under different treatments may be ranked in the order of $\mathrm{T} 4\left(6.20 \mathrm{tha}^{-1}\right)$ $>$ T5 $\left(6.13 \mathrm{tha}^{-1}\right)>\mathrm{T} 3\left(6 \mathrm{t} \mathrm{ha}{ }^{-1}\right)>\mathrm{T} 2\left(5.83 \mathrm{tha}^{-1}\right)>\mathrm{T} 1\left(3.27 \mathrm{t} \mathrm{ha}^{-1}\right)$. Application of organic fertilizer encouraged the vegetative growth of rice in terms of plant height and number of tillers per hill which ultimately resulted in the increase of grain yield [27].

The straw yield varied from 4.5 to $8.83 \mathrm{tha}^{-1}$ under different treatments (Figure $3 \mathrm{~b}$ ). The highest straw yield of $8.9 \mathrm{t} \mathrm{ha}^{-1}$ was obtained in treatment T4 (50\% well decomposed kitchen waste $+50 \%$ chemical fertilizer) and the lowest yield of $4.5 \mathrm{t} \mathrm{ha}^{-1}$ was obtained in T1. Straw yield under different treatments may be ranked in the order of T4 $\left(8.9 \mathrm{tha}^{-1}\right)>\mathrm{T} 5\left(8.83 \mathrm{t} \mathrm{ha}^{-1}\right)>\mathrm{T} 2(8.33 \mathrm{t}$ ha $\left.^{-1}\right)>$ T3 $\left(8.1 \mathrm{tha}^{-1}\right)>\mathrm{T} 1\left(4.5 \mathrm{ha}^{-1}\right)$. Combined application of NPK and organic manures also increased the straw yield of rice [26].
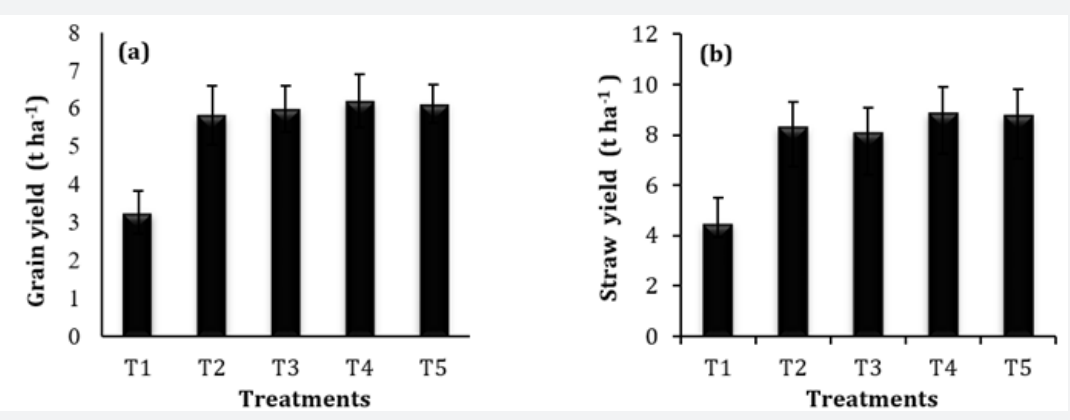

Figure 3: (a) Grain and (b) straw yield under different treatments.

\section{Conclusion}

Bacterial population was higher in kitchen waste amended soil. On the other hand, fungal and nematode population was higher in farm waste and municipal waste amended plot. $\mathrm{CH}_{4}$ emission was much higher from kitchen waste and municipal waste treated plot compared to farm waste. However, there was no significant variation in growth and yield among three waste materials applied plots. From this study, it is found that farm waste is suitable for getting higher microbial population as well as growth and yield of rice with little $\mathrm{CH}_{4}$ emission.

\section{Acknowledgement}

The study was conducted with the financial support of Bangladesh Agricultural University Research System (BAURES), Mymensingh, Bangladesh.

\section{References}

1. Rahman MM, Yakupitiyage A (2006) Use of fishpond sediment for sustainable aquaculture-agriculture farming. International Journal of Sustainable Development and Planning 1(2): 192-202.

2. Rahman N (2010) Solid waste management plan for Indian megacities. Indian Journal of Environmental Protection 19: 90-95.
3. Albiach R, Canet R, Pomares F, Ingelmo F (2000) Microbial biomass content and enzymatic activities after the aplication of organic amendments to a horticultural soil. Bioresource Technology 75(1): 43-48.

4. Masciandaro G, Ceccanti B, Garcia C (2000) In-situ vermicomposting of biological sludges and impacts on soil quality. Journal of Soil Biology and Biochemistry 32(7): 1015-1024.

5. Hill E, Wood B, Blundy J (2000) The effect of waste component on cropping pattern between clinopyroxene and silicate melt. Lithos 53: 203-215.

6. Lazarovits G (2001) Management of soil borne plant pathogens with organic soil amendments: a disease control stratagem salvaged from the past. Journal of Plant Pathology 23: 1-7.

7. Domingues J, Edward CA, Webster M (2003) Vermicomposting of sewage sludge: effect of bulking materials on growth and reproduction of the earthworm. Journal of Pedobiologia 44(1): 24-32.

8. Ayuso M, Hernandez T, Garcia C, Pascual J (1996) Stimulation of barley growth and nutrient absorption by humid substances originating from various organic materials. Bioresearch Technology 57(3): 251-257.

9. Hellmann AK, Briegleb HP, Minschwaner K, Wuebbles D (1997) Radioactive forcings and global warming potentials of greenhouse gases. International Geophysical Researsh 105(D16): 20773-20790.

10. Jackson ML (1962) Soil chemical analysis. Prentice-Hall, Englewood Cliffs, N.J. 498 
11. Olsen SR, Cole CV, Watanable FS and Dean LA (1954) Estimation of available phosphorus in soils by extraction with sodium bicarbonate. United State Department Agricultural Research. p. 929.

12. Black CA (1965) Methods of Soil Analysis. Part-II. American Social Agronomy Institute. Medison, Washington, USA, pp. 999-1492.

13. Page AL, Miller RH, Keney DR (1982) Methods of Soil Analysis, Part-2. 2nd Edition American Social Agronomy Institute, Madison, Washington, USA, pp. 98-765.

14. Ali MA, Oh JH, Kim PJ (2008) Evaluation of silicate iron slag amendment on reducing methane emission from flood water rice farming. Agriculture, Ecosystems and Environment 128(1-2): 21-26.

15. Rolston DE (1986) Gas flux. In: Klute A (Ed.), Methods of Soil Analysis, part 1. ( $2^{\text {nd }}$ edn), Agronomy Monograph. ASA and SSSA, Madison, WI 9: 1103-1119.

16. Goyal AP, Shastri GS, Narwal RP (2001) Effect of various organic manures and on soil microbial bacteria. Indian Journal of Agricultural Science 55(4): 256-261.

17. Ginting G, Singh RR, Pavitro K (2003) Influenced of straw mulch and transpiration suppressants on soil temperature, dry matter and microbial community and nutrient uptake by dry land rice. Indian Journal of Biological Science 46: 126-131.

18. Verma LN (1995) Conservation and efficient use of organic sources of plant nutrients. Organic agriculture. Peekay Tree Crops Development Foundation. India, pp. 101-143.

19. Cleveland CC, Nemergut DR, Schmidt SK, Townsend AR (2007) Increases in soil respiration following labile carbon additions linked to rapid shifts in soil microbial community composition. Biogeochemistry 82(3): 229-240.
20. Jahangir A (2012) Effect of organic amendments on methane emission and rice productivity at Bangladesh Agricultural University farm. MS thesis, Environmental Science Department, Bangladesh Agricultural University, Mymensingh.

21. Khosa M, Sidhu B, Benbi DK (2010) Methane emission from rice fields in relation to management of irrigation water. Journal of Environmental Biology 32(2): 169-172.

22. Denier VD, Gon HAC (1999) Changes in $\mathrm{CH}$ emission from rice fields from 1960 to 1990s: The declining use of organic inputs in rice farming. Global Biology, Geology and chemistry 13(4): 1053-1062.

23. Yagi K, Minami K (1990) Effects of organic matter application on methane emission from some Japanese paddy fields. Soil Science and Plant Nutrition 36: 599-610.

24. Inubushi K, Umebayashi, Wada H (2004) Control of methane emission from paddy soil. Paper presented at $14^{\text {th }}$ International Congress of Soil Science Kyoto, August 1990.

25. Muhammad B (2004) Effect of sewage sludge on the growth and yield of rice (cv. BRRI dhan- 33). MS Thesis, Deprtment of Environmental Science, Bangladesh Agricultural University, Mymensingh.

26. Khan SD, Rabbi F, Prohit S (2007) Effect of farm waste and organic manure on soil properties, nutrient availability and yield of rice, wheat grain on sodic vertisol. Indian Journal of Agricultural and Biological Science 42: 253-256.

27. Mishra T, Nair SS, Darri SK (2003) Physical and chemical properties of rice soils as influenced by organic and inorganic sources of nutrients. Indian Journal of Agricultural Research 35: 432-441.

\begin{tabular}{|l|}
\hline \multicolumn{1}{|c|}{ Your next submission with Juniper Publishers } \\
will reach you the below assets \\
- Quality Editorial service \\
- Swift Peer Review \\
- Reprints availability \\
- E-prints Service \\
- Manuscript Podcast for convenient understanding \\
- Global attainment for your research \\
- Manuscript accessibility in different formats \\
( Pdf, E-pub, Full Text, Audio) \\
- Unceasing customer service \\
Track the below URL for one-step submission \\
https://juniperpublishers.com/online-submission.php \\
\hline
\end{tabular}

